\title{
Judging in lower courts: \\ Conventional, procedural, therapeutic and feminist approaches
}

\author{
Rosemary Hunter \\ School of Law \\ Queen Mary, \\ University of London \\ Mile End Road, London E1 \\ 4NS, United Kingdom
}

\author{
Sharyn Roach Anleu \\ School of Social \& Policy \\ Studies \\ Flinders University \\ GPO Box 2100, Adelaide \\ 5001, South Australia, \\ Australia
}

\author{
Kathy Mack \\ School of Law \\ Flinders University \\ GPO Box 2100, Adelaide \\ 5001, South Australia, \\ Australia
}

\section{Correspondence to}

Professor Kathy Mack

Email: $\quad$ judicial.research@flinders.edu.au

Phone: $\quad+6182015537$

Mail: $\quad$ Flinders University, GPO Box 2100, Adelaide SA 5001 Australia

\section{Acknowledgement}

Funding for this research includes: a 2001 University-Industry Research Collaborative Grant with Flinders University and the Association of Australian Magistrates (AAM) and financial support from the Australasian Institute of Judicial Administration (AIJA); an Australian Research Council (ARC) Linkage Project Grant (LP0210306) with AAM and all magistrates courts; an ARC Linkage Project Grant (LP 0669168) with the magistrates courts of Victoria, South Australia and the Northern Territory as well as the AIJA; four ARC Discovery Project Grants (DP0665198, DP1096888, DP120102375, DP150103663); and an Economic and Social Research Council (ESRC) Small Grant (ES/G008906/1). We are grateful to several research and administrative assistants over the course of the research, and to Colleen delaine, Jordan Tutton and Rae Wood for assistance on this article and to Professor Margaret Davies and Professor Kate Malleson for their helpful suggestions. 


\section{Abstract}

Recent theorising about feminist judging has concentrated on appellate courts and their judgments. This article develops a conceptualisation of feminist judging in lower, first instance courts, which are dominated by high case volume and limited time for each matter, with decisions given orally and ex tempore rather than in elaborated written judgments. Through careful accounts of the philosophy, goals and practices of conventional as well as newer, more engaged approaches to judging, the article compares and contrasts feminist judging with other approaches to judging in the lower courts. This entails considering elements such as the judicial officer's orientation to substantive law and practice in court, concepts of fairness, ethical commitments, the view of the defendant, and judicial qualities and capacities.

\section{Introduction}

Theorising around the practice of feminist judging has burgeoned in recent years, most notably in feminist judgment projects. ${ }^{1}$ Much of this work has focused on appellate courts, and on written judgments (the outputs of judging) and their contents. At the other end of the court hierarchy, by contrast, judicial officers in lower courts handle a high volume of mostly criminal cases with very little time for each matter. ${ }^{2}$ Decisions often address routine procedural matters such as adjournments or granting or denying bail which are rarely contested (see Roach Anleu and Mack, 2009). Even when giving judgment or imposing sentence, formal, elaborated, written judgments are rare; decisions are usually given orally, ex tempore and with only a brief explanation (Bolton, 2012; Hunter, 2008b; Mack and Roach Anleu, 2007, 2010).

This gives rise to the question: what might constitute feminist judging in the lower courts? In order to answer this, it is necessary to analyse the process of judging - the way judicial officers manage the courtroom and interact with litigants, witnesses, lawyers and prosecutors, as well as (or instead of) the content of decisions (Hunter, 2008a; Mack and Roach Anleu, 2012). In contrasting feminist judging with conventional judging, ${ }^{3}$ it is also necessary to consider other approaches to judging

\footnotetext{
${ }^{1}$ Feminist judgment projects have produced alternative judgments for significant legal cases in Australia, England and Wales, and Canada: Douglas et al., 2014a; Hunter et al., 2010; Women's Court of Canada; Majury, 2006. Similar projects are underway for judgments in international law, Ireland and Northern Ireland, the United States Supreme Court, and Aotearoa/New Zealand: IntLawGrrls, 2014; Northern/Irish Feminist Judgments Project, 2015; US Feminist Judgments Project, 2015; New Zealand Law Society, 2015; see also Brems, 2013.

For a discussion of feminist judging generally, see Baines, 2013; Hunter, 2008a; Hunter, 2013. For a discussion of feminist judgment projects, see Hunter, 2010, 2012a, 2012b, 2015a; Rackley, 2012.

${ }^{2}$ Lower courts also handle civil matters such as small claims, judgment debt and housing possession cases. See, to give only a few examples, Bezdek, 1992; Bolton, 2012; Carlen, 1976; Cowan and Hitchings, 2007; Mack and Roach Anleu, 2007; O'Barr and Conley, 1985.

${ }^{3}$ We use the term 'conventional' judging to refer to the traditional conception within an adversarial system of the judge as a passive, impartial adjudicator, with all that that entails (see section 3 below).
} 
which a judicial officer may take. When examining judicial practices, as opposed to the content of written decisions, how different is feminist judging from other, newer forms of 'engaged' judging (Mack and Roach Anleu, 2011)?

This article develops a conception of feminist judging in the lower court context, distinguishing it from a conventional approach to judging and from two major forms of more engaged judging, procedural justice ${ }^{4}$ and therapeutic jurisprudence. Our focus is on lower courts in common law adversarial systems, and hence we draw primarily on literature from the United States, United Kingdom, Canada, Australia and New Zealand.

Distinguishing feminist judging from the other forms of judging requires careful accounts of all four approaches. Judging is a practice which consists of an accumulation of individual and institutional behaviours, norms, attitudes, approaches and actions, enacted or performed by a judicial officer in a specific context (in this analysis, a lower court). Practices are integrally connected with an approach or a guiding philosophy about the nature of judging or the judicial role, even if that guiding philosophy is implicit and not articulated by the practitioner. For this reason, approach can sometimes be discerned from practice.

The accounts that follow first articulate the underlying philosophy or goals of each approach, and second identify practices that are associated with each philosophy or set of goals. This structure is adopted for the purposes of analysis, to enable clearer accounts of the similarities and differences of the four approaches. It is not intended to imply a necessary linear or causal relationship between philosophy and practices, nor to reify a categorical distinction between them which may in reality be somewhat blurred. The accounts of both philosophies and practices are based largely on academic commentaries, but sources also include judicial reflections, empirical studies and law reform and policy documents. These accounts consider elements such as the judicial officer's orientation to law and procedure, concepts of fairness, the view of the defendant, ethical orientation, and judicial qualities and capacities. They concentrate on judicial work in criminal matters and on its performance in lower courts, which impose particular constraints on and opportunities for different approaches to judging. Once the philosophies and practices associated with each approach are identified, they can be compared and contrasted to discern key points of convergence and divergence. Disentangling the key characteristics of different approaches is essential for gaining a clear understanding of what scholars and practitioners mean when they refer to particular approaches to judging.

However, identifying differences among judicial philosophies and practices is complex. Newer forms of judging, such as therapeutic jurisprudence, which demand a more engaged judicial officer may share features with feminist approaches, for example, in their critique of abstract, rule-bound

\footnotetext{
${ }^{4}$ Here we mean procedural justice in the social psychological sense, as elaborated by Lind, Tyler and others, not the formal procedural fairness requirements as expressed in administrative law (Lind and Tyler, 1988; Rottman and Tyler, 2014; Tyler, 1990; Tyler, 2003).
} 
decision making. These forms of judging all argue for a shift from judging that is essentially 'peopleprocessing' (Lipsky, 2010, p. 10; see also Borowski, 2013), treating people as abstractions or categories, e.g. 'defendant' (Borowski, 2013, p. 283), to judicial engagement with individual people in particular situations. ${ }^{5}$ As Margaret Davies points out, characteristics associated with feminist judging such as a relational approach or empathy are not exclusive to feminist judging (Davies, 2012). Because of this potential for overlap, distinctions will need to be drawn explicitly and concretely.

\section{The context for judicial performance: Judging in lower courts}

Judicial performance is undertaken in a context made up of many different elements including local practices and case variation, organisational requirements and wider social or political structures (Annison, 2014; Gibson, 1980). Courts and judging are bounded and diverse at all levels, so it is necessary to articulate the institutional context of courts generally and lower courts specifically, to identify ways that different approaches to judging can be manifest even within a bounded location. In all courts, the nature of judging generally will limit the capacity of judges to judge differently. In adversarial systems, judicial legitimacy is linked to a particular judicial role constrained by law, by fact, and by commitments to judicial values of impartiality, integrity and the rule of law (Epstein et al., 2013; Hunter, 2008a; Hunter, 2015b).

However, judicial officers might adopt a variety of styles of performing their work and these styles of judging can be context dependent, or relational, rather than simply a function of personal attributes or judicial philosophy (Cowan and Hitchings, 2007; Cowan et al., 2006; Hunter et al., 2008; Lens, 2012; Smith and Blumberg, 1967). The work of judicial officers relies on the activities and inputs of others; it is not just a product of their own individual behaviour (Eisenstein et al., 1988; Mather, 1979; Tata, 2007). In analysing judicial practices, therefore, it is important to be mindful of the conduct of others to which the judicial officer may be responding as well as the recipient or audiences for the behaviour. Such an approach avoids viewing judicial performance as abstracted from the multiple contexts of judicial work (Roach Anleu and Mack, 2014).

A key aspect of context for the analysis of judging in lower courts is the opportunity and/or demand for judicial interaction. Unrepresented litigants present particular challenges in all courts, but especially so in summary proceedings (Moorhead, 2007). For example, 57 per cent of Australian

\footnotetext{
${ }^{5}$ We acknowledge that there have always been judges who have spoken directly to the individuals appearing before them, often with very personalised comments. However these forms of judicial 'engagement' often entailed authoritarian or moralising qualities: see, eg, the 'situational sanctions' described by Mileski (1971, p. 521-531) or degradation ceremonies discussed by Carlen (1976) and Garfinkel (1956). Our concern in this article is with newer forms of engaged judging whose goals/purposes are more inclusive or transformative.
} 
magistrates ${ }^{6}$ indicate that their time is always or often taken up explaining things to unrepresented litigants compared with less than 10 per cent of judges in the higher courts (Mack and Roach Anleu, 2011). Unrepresented defendants may require or enable more direct engagement from the magistrate, in contrast to a legally represented defendant. This face-to-face interaction may create greater demand and/or opportunity for engagement (Goffman, 1955). Even where defendants appear with legal representation, the nature of many of the proceedings in lower courts, especially sentencing, entails direct communication between the magistrate and the defendant (Mack and Roach Anleu, 2011).

Other features of the lower court environment include the pressure of time and the volume of cases coupled with the need to meet court efficiency performance measures, limited information or ability to elicit information (whether from the parties or other sources), and limited responses in terms of decisions, including sentencing (Mack and Roach Anleu, 2011; Roach Anleu and Mack, 2013b; Hunter, 2005; Mileski, 1971). Judicial officers are aware of the practical contingencies of their work context and need to manage them in various ways (Fielding, 2011; Mack and Roach Anleu, 2007). The effect is that there may be limited opportunities for varied approaches to judging to take place in lower courts, when routinisation appears so inevitable and necessary (Hunter, 2005; Mack and Roach Anleu, 2010; Mileski, 1971).

In spite of these distinct lower court challenges, this is a site where feminist and other engaged forms of judging could have broad scope and relevance. These courts deal directly with a large number of individuals; inequalities and disadvantages are starkly visible. Legal representation is limited, and where it exists may be poorly prepared or inexperienced (Bolton, 2012; Mack et al., 2012). As the 'peoples' court' or the metaphorical face of the justice system, they provide more opportunity for judicial officers to interact directly with individuals (Roach Anleu and Mack, 2007). Lower courts are also the courts where there are more women judicial officers (Australasian Institute of Judicial Administration, 2015; Courts and Tribunal Judiciary (UK), 2014), though being a woman does not necessarily entail taking a feminist approach (see, for example, Hunter, 2008a). Further, lower courts are the location where the most common form of gendered crime - domestic violence - appears regularly, whether in the form of restraining order applications or criminal charges (Hunter, 2008b). And they are the courts which deal most often with the kind of repeat, low-level offending, sanctioning and re-offending which has given rise to calls for new interventions to halt the 'revolving door' of criminal justice (King et al., 2014).

\footnotetext{
${ }^{6}$ Each Australian state and territory has a magistrates court (called the Local Court in New South Wales) and a supreme court. The five most populous states have an intermediate trial court (named the district or county court), which hears criminal jury trials and civil matters without juries. Magistrates courts in the Australian states and territories are first-instance courts of general jurisdiction. Unlike the lay magistrates of England and Wales, Australian magistrates are paid judicial officers, nearly always full time, with legal qualifications, and appointed until a fixed retirement age: Roach Anleu and Mack, 2008. They sit alone without juries, in regional and remote areas as well as in capital cities; those who appear in these courts are often unrepresented. Over 90 per cent of all civil and criminal cases are initiated and finalised in the lower courts: Mack and Roach Anleu, 2007; Australian Government Productivity Commission, 2015. For more detail regarding Australian courts and the judiciary see Crawford and Opeskin, 2004; Lee and Campbell, 2013.
} 


\section{Conventional judging}

\section{Philosophy}

Judicial legitimacy in an adversarial legal system is based on a particular concept of neutrality of judicial authority (Australasian Institute of Judicial Administration, 2002; Australian Law Reform Commission, 2000; King et al., 2014). The judge is expected to display a particular form of detached impartiality, participating actively only when a decision, ruling or order is required by the parties (Australian Law Reform Commission, 2000; Berman, 2000; Farole, 2009; King et al., 2014; Shaman, 1996). This conventional judge is disembodied, objective, unemotional and impersonal (Maroney, 2011a, 2011b; Maroney and Gross, 2014; Shaman, 1996). Law, fact and reason are the legitimate sources for judicial decisions, not a personal choice of the judicial officer (Malleson, 1999; Moorhead, 2007; Tamanaha, 2010). This view was reflected by Justice Sonia Sotomayor at her US Senate confirmation hearings, where she asserted '[i]t's not the heart that compels conclusions in cases, it's the law' (United States Senate Committee on the Judiciary, 2009; see also Lithwick, 2009). Under this conception of judicial authority, the judge embodies impartial legal authority. When applying law, personal views, biases, values and emotions should be set aside, and so the identity or social characteristics of judges should not affect the decisions made (Bybee, 2010; Moran, 2009, 2010).

The focus of this approach is on formal procedures defined by law, as the means to enforce existing substantive law. Such conventional judging is thought to reflect the importance of formal due process (Chriss, 2002) to protect legal rights and to limit 'scope for accusations of bias and favouritism' (Bean, 2002, pp. 249-250). Depersonalisation and abstraction are central to conventional understandings of the adversarial judicial role (Bandes, 2009; Maroney, 2011b; Maroney, 2011a). Litigants and facts are abstracted and categorised to ensure that 'like cases are treated alike'. Even in the context of sentencing, when a defendant's personal characteristics and individual circumstances must be taken into account, this is done in a structured, often routinised and categorical way which is designed to achieve consistency between similar cases (Heimer, 2001; Emerson, 1983). Abstraction enables cases to be determined according to law, without (illegitimate) regard to a defendant's personal characteristics, and limits the impact of individual judicial attitudes or preferences.

An important consequence of this legalistic approach is to insulate the judicial officer from personal responsibility to address the wider social needs of those who appear in court (Farole et al., 2005; King et al., 2014; McCoy, 1997). As former Chief Justice John Doyle of the South Australian Supreme Court has stated, the judicial role 'is to decide disputes [and to] administer justice according to law ... [and to] decide cases on the material presented. ... It is not for us to pursue 
social policies, or to press for social change. We have no charter to remedy social problems' (Doyle, 2001, emphasis omitted; see also Roach Anleu and Mack, 2007).

\section{Practice}

The legitimacy of judicial decisions is formally based in law, and judicial officers exercise their authority every day in court settings bounded by legally defined rules, procedures and roles (Gleeson, 2010; Heydon, 2012; Australasian Institute of Judicial Administration, 2002). Using legal language, following prescribed procedures, and observing delineated professional roles reinforce formal judicial authority and legitimacy as does courthouse and courtroom design (Mulcahy, 2007; Mulcahy, 2011; Resnik and Curtis, 2011; Tait, 2002; Tamanaha, 2010).

Legal authority must be supported by appropriate performance on the part of the judicial officer the 'outward countenance' (in Hochschild's terms) (Hochschild, 1983, p. 7). The conventional judging philosophy is thought to require judges to display a demeanour that communicates impartiality through impersonality, emotional detachment and disinterestedness (Baker, 1994; Bandes, 2009; Bean, 2002; Bybee, 2010; Maroney, 2011b; Maroney, 2011a; Moorhead and Cowan, 2007; Popovic, 2002; Shaman, 1996; Nussbaum, 1996). An impersonal demeanour and a lack of emotional expression are thought to demonstrate that judicial decisions are impartial, compelled by law, fact and reason and not based on personal choice or emotion (Mack and Roach Anleu, 2010, 2011; Moorhead and Cowan, 2007; Roach Anleu and Mack, 2005, 2013a). The capacity to produce such a performance may be among the qualities identified by judicial appointments processes, and feature in professional training programs (see, for example, Judicial Appointments Board for Scotland; Judicial Appointment Commission (UK); see also Australasian Institute of Judicial Administration, 2002; American Bar Association, 2007; Gleeson, 1998; Thomas, 1997).

The conventional understanding of neutrality in an adversarial system, for example, would ordinarily prevent a judicial officer from engaging directly with a legally represented participant present in court. If the participant is legally represented, the judicial officer formally interacts with the lawyer, not the party. While legal representation is undoubtedly beneficial to participants, it can have the effect of rendering them more removed from and less visible in the proceedings, especially if the judicial officer does not engage with them in any way (Douglas and Laster, 1992; Freiberg, 2007; King et al., 2014; Popovic, 2002).

Sentencing is a key location where a philosophy of judging may manifest itself in everyday practice. Sentencing in Australia, for example, is often an area of wide judicial choice (Mackenzie et al., 2010), and most sentencing decisions in lower courts are given ex tempore (Bolton, 2012; Roach Anleu and Mack, 2013b). An impersonal judicial manner may be especially appropriate during 
sentencing, as a way to reinforce the wrongfulness of the criminal conduct (Hunter, 2005; Ptacek, 1999; Were $v$ Police [2003] SASC 116).

When a judicial officer imposes sentence, giving reasons is often legally required (Australian Law Reform Commission, 2006; Mackenzie, 2005). Communicating reasons allows the magistrate to highlight the law and facts that underpin the sentence, distancing her- or himself from personal responsibility for the substance and effect of the decision (Roach Anleu and Mack, 2013b; Tata, 2007). Stating the basis for the decision, including specific legal requirements, reinforces the conventional adversarial norm of the judge as a neutral decision-maker who must apply the law, and demonstrates that the sentence results from a dispassionate evaluation rather than from bias or emotional reaction (Roach Anleu and Mack, 2005; Thomas, 1963).

These elements of practice can reflect a conventional judging philosophy and reinforce the formal legitimacy of the exercise of judicial authority in conventional terms.

\section{Procedural justice judging}

\section{Philosophy}

A different philosophy of the judicial role is derived from research which emphasises the importance of relational or interactive qualities to the legitimate exercise of authority, including judicial authority (Fiss, 1983; Tyler, 1984, 1988). While conventional judging implicitly values judicial behaviours such as courtesy, a procedural justice approach to judging recognises the extent to which judicial authority depends on the 'quality of the interpersonal treatment that people experience' (Tyler, 2003, p. 350). Those who experience or observe judicial behaviours which effectively communicate respect for the humanity and individuality of people appearing in court may attribute legitimacy-enhancing attitudes or feelings to the judicial officer. Showing human respect for another human person may indicate, or be perceived as indicating, that the judicial officer cares about the welfare of the person appearing in court, or is committed to values of justice and fairness. Tyler expands on the nature of the treatment which will elicit this legitimacyenhancing response:

treatment with dignity and respect, acknowledgment of ... rights and concerns, and general awareness of the importance of recognizing people's personal status and identity and treating those with respect, even while raising questions about particular conduct. ... [A] key issue to people when dealing with legal authorities is the respect and dignity with which they are treated (Tyler, 2003, pp. 350-351; see also Tyler, 2000).

Empirical research confirms the value of procedural justice as an approach to judging. This procedural justice effect has been observed in defendants in summary proceedings, including 
when being sentenced. A judicial officer who treats the defendant with respect when imposing a sentence will elicit greater acceptance of the decision than a sentence delivered in way that does not display elements of procedural fairness (Tyler, 1984; Casper et al., 1988).

The finding that the way a judicial officer delivers a decision, including imposing sentence, can have as much or even more impact on perceptions of fairness and legitimacy than the actual decision or sentence itself raises the question of the relationship between the display of procedural justice behaviours and the substance of the decision. The procedural justice literature tends not to question substantive decisions, or assumes that they are themselves 'correct' and 'legitimate' (MacCoun, 2005). The procedural justice focus is on the conduct of the person in authority, and the impact of that conduct on perceptions of legitimacy. A judge [who] is seen as having taken enough time to consider the case carefully and as unbiased' (Tyler, 1984, p. 67) will enhance the authority and legitimacy of the court's decisions.

In a sense, these findings confirm the importance of a perception that the judge is doing his or her job properly in light of conventional norms. Arguably, procedural justice is partly about behaviour that better operationalises conventional judging norms and values than the conventional detached performance. However, a humanist element distinguishes the procedural justice approach from the conventional approach, with its explicit concern with the litigant's dignity and their experience of the proceedings. It is the difference between the litigant or defendant as a category and the litigant/defendant as an individual deserving to be listened to, to receive explanations, and to have their voice validated by the judge.

\section{Practices}

Four key elements of procedural justice as a practice are:

1. Voice, allowing opportunities for parties to participate or express views

2. Neutrality, including transparency, principled decisions, lack of bias

3. Respect shown by treating people with dignity

4. Trustworthiness, generated by listening, explaining, justifying decisions (Tyler, 2007-2008, pp. 30-33; Burke and Leben, 2007-2008, p. 6)

Burke and Leben provide more concrete advice about judicial practices to implement a procedural justice approach. This entails qualities and behaviours such as:

- Using understandable language, even if the participant has a lawyer

- Listening better

- Showing patience and thanking those in court for their patience

- Explaining ground rules early, such as the order in which cases are called

- Making the courtroom work for all participants, including unrepresented parties 
- Developing court procedures to support communication that will enhance perceived fairness (Burke and Leben, 2007-2008, pp. 18-19)

The considerable, relatively informal interaction which may occur between the judicial officer and the parties in lower courts, especially with unrepresented parties, may allow judicial officers to communicate with a participant in ways that will enhance perceived procedural fairness (Tyler, $1984,1990,1988)$. Conduct associated with procedural fairness might include a judicial officer communicating effectively to a defendant, such as by explaining processes and decisions carefully (Mack and Roach Anleu, 2011; Roach Anleu and Mack, 2013b). Meeting ordinary conversational expectations, such as looking at and speaking directly to a defendant, conveys respect. This kind of direct engagement and the respect it implies are key elements of the values of procedural justice, going beyond conventional judicial norms and behaviours of formal courtesy.

The content of the judicial officer's engagement with the defendant may also evince procedural justice. When a defendant is to be sentenced, the judicial officer will be given information about the defendant, including personal and family background, any work history or previous offending. The judicial officer is expected to listen carefully so that this material is part of the process of reaching a decision on sentence. A judicial officer who clearly communicates how the individual circumstances of the defendant have been considered shows that the defendant is regarded as a person, not as an abstraction or category: e.g. defendant or shoplifter.

While the practical context of a lower court can enhance opportunities for procedural justice practices, it can also limit them. In particular, there are severe limits on the time available for a judicial officer to engage with each participant and to provide the more individualised attention necessary to achieve procedural justice (Mack and Roach Anleu, 2007). This time pressure may sometimes lead to rushed or inconsiderate treatment of participants and so undermine procedural justice goals (Mack and Roach Anleu, 2010; Burke and Leben, 2007-2008).

Active judicial conduct to achieve procedural justice goals also depends on the practical cooperation of others, in and out of court. Because such engagement may appear to conflict with the formally passive judicial role of conventional norms, there may be resistance to greater judicial engagement (Burke and Leben, 2007-2008). This may require the judicial officer to ensure visible compliance with important adversarial norms, while implementing procedural justice values, to maximise the support for judicial authority.

\section{Therapeutic judging}

\section{Philosophy}


Therapeutic jurisprudence conceptualises legal processes in relation to the physical, emotional and psychological wellbeing of the participants (King and Ford, 2006; Wexler and Winick, 2003, p. 54; McMahon and Wexler, 2002; Wexler, 2000). In the past, law, particularly in the form of criminal punishment, has had harmful consequences for defendants, especially those experiencing mental illness, and/or other psycho-social problems (King et al., 2014). Judicial and academic proponents of therapeutic jurisprudence, put forward a new way of thinking about law and legal authority as a vehicle to maximise the therapeutic and minimise the non-therapeutic effects of law, bring about positive change, enhance wellbeing or at least 'to do no harm' (Winick, 2002-2003, p. 1063; King, 2008). The general philosophy of therapeutic jurisprudence is that certain law-breaking behaviour is symptomatic of deeper social, economic and personal problems. Because conventional legal process does not effectively address these problems, or disclaims responsibility for addressing them, offending behaviour will often continue. Therapeutic jurisprudence, by contrast, recognises that people in court have unaddressed problems and seeks to encourage them to acknowledge and address these problems (Winick, 2002-2003, pp. 1061, 1067). Rather than regarding the defendant as a rational actor responding to the level and probability of sanctions for their behaviour, the role of a therapeutic judge is 'to motivate offenders to engage in treatment and to develop plans to eliminate or reduce unhealthy or anti-social behaviours...and replace them with healthy behaviours' (Wiener et al., 2010, p. 419-422). In doing so, persuasion rather than coercion is key (Winick, 2002-2003, p. 1078). 'Therapeutic jurisprudence values self-determination as it activates motivation and other inner resources needed for successful action, and recognises that coercion and paternalism have the reverse effect and promote resistance to change' (King, 2008, p. 1115).

A judicial officer who implements a therapeutic jurisprudence approach to judging will provide a more individualised intervention, which aims to enable a defendant to overcome drug addiction or other problems which have led to criminal offending. These interventions, which may require participation in drug treatment, education or training programs, coupled with stringent conditions such as drug testing, overseen regularly by a judicial officer, are expected to promote self-esteem and to help ameliorate some of the consequences of economic disadvantage and social marginalisation (Nolan, 1998; Burns and Peyrot, 2003; see also Berman and Feinblatt, 2001; Freiberg, 2001; Goldberg, 2005; Phelan, 2003, 2004).

Therapeutic jurisprudence thus espouses a commitment to therapeutic agency on the part of the judicial officer that emphasises engagement, understanding, assistance, motivation, guidance, encouragement, affirmation and treatment (Winick, 2002-2003, pp. 1065-1068). Goldberg reiterates this: 'Direct interaction between a judge and court participants is a foundation of problemsolving judging, and a prerequisite for effective behaviour modification and for change' (Goldberg, 2005, p. 9). This contrasts with the conventional judicial emphases on detachment and neutrality (Emerson, 1969). The judicial officer committed to a therapeutic jurisprudence approach cares what will happen to the defendant, but that care is bounded by strong limits: the participant must 
comply with treatment requirements and be committed to change or provide an acceptable account. If these elements do not exist, judicial 'care' may revert to conventional judicial authority to impose sanctions.

The philosophy of therapeutic judging necessarily implies power and inequality in a relationship (see Rieff, 1966; Winick, 2002-2003, p. 1060; Wright, 2010). Perhaps implicitly, therapeutic jurisprudence adopts a model of the individual participant as sick and requiring treatment. It draws on sources of authority and social control in addition to law - medicine and psychology - to provide diagnosis, treatment and cure. The care and treatment provided within the therapeutic process thus operates as a form of regulation, an exercise of biopower in Foucauldian terms (Rabinow and Rose, 2006; Rose, 1993; Rose and Miller, 1992; Rose et al., 2006). The relationship and interaction between the judge and the participant are asymmetrical, not egalitarian. The judicial officer's role is to help, seek information on, support and empathise with the participant, not vice versa. It is the problems of the participant that require correction, and the judicial officer retains legal authority to offer solutions and to punish non-compliance (Moore, 2007; Moore et al., 2011).

\section{Practices}

The active problem-solving agenda which is central to the therapeutic jurisprudence philosophy operates on two levels in practice: the interaction between the judicial officer and the court participant, and the adoption of an interdisciplinary approach to problem solving, involving a range of professional input, most often institutionalised in problem-solving courts.

Therapeutic jurisprudence focuses on the relationship between the judicial officer and court participant, and the interaction between the two as having therapeutic potential. In this interaction, the input of the judicial officer is key (King, 2003, 2006; Mclvor, 2009). Therapeutic jurisprudence values warmth, openness, emotional attachment, empathy, respect, active listening, a positive focus, non-coercion, non-paternalism, clarity, and plain language (Winick, 2002-2003, p. 1068; Winick and Wexler, 2003; Goldberg, 2005).

The practical implementation of therapeutic jurisprudence occurs most typically in problem-solving courts. Although 'it is important to distinguish problem-solving courts (a practical legal innovation) from therapeutic jurisprudence and restorative justice (theories of justice generated within the academic world)' (Nolan, 2003, p. 1546; see also Braithwaite, 1989; Hora et al., 1999) these courts are the primary site where the philosophy of therapeutic jurisprudence is practised.

The therapeutic solution to personal problems as practised in problem-solving courts requires an interdisciplinary approach. Judicial authority, in tandem with other professional disciplines (especially helping professions, social work, counselling, psychology) develops a program which 
the court participant must follow in order to change their lives and desist from offending. ${ }^{7}$ ' $[E] x p e r t$ knowledges are freed from expert actors' (Moore, 2007, p. 44). Judges adopt the language of therapy and draw on information and knowledge from psychology and wellbeing, while counsellors and psychologists frame information and concerns in legal language and processes.

Often in problem solving courts, the judicial decision may not be about punishing the defendant's criminal behaviour as in sentencing, or about legal process as in a bail application, but is directed towards determining the defendant's compliance with the treatment program and the appropriate consequence of non-compliance, often relying on advice from social services or other 'expert' personnel.

Proponents argue that therapeutic jurisprudence need not be limited to problem-solving courts, and that all judicial officers can implement a therapeutic jurisprudence approach (Bartels, 2009; Goldberg, 2005). 'Every judicial officer is able to minimise negative effects and to promote positive effects on participant well-being through the nature of the interaction that takes place between the bench and the party involved' (King, 2003, p. 172; see also Wexler and Winick, 1991). A judicial officer who wishes to take a therapeutic jurisprudence approach in a general criminal court will need to understand social or psychological factors relating to criminal behaviour, which may involve working with social services professionals. In court, a judge implementing therapeutic jurisprudence principles will engage more actively and less formally with the defendant and will undertake steps to facilitate access to necessary services.

Whether in general criminal courts or in problem solving courts, a key element in therapeutic jurisprudence is a more active judicial officer (King, 2003; King and Auty, 2005; King and Wager, 2005; McMahon and Wexler, 2002; Wexler, 2000). As Popovic has pointed out: 'the therapeutic jurisprudence approach requires judicial officers who are prepared to modify their judicial style and to embark on a new form of "court-craft"' (Popovic, 2002, p. 128). A judicial officer who undertakes a therapeutic jurisprudence approach will develop enhanced interpersonal skills, be more aware of the personal circumstances of defendants when they appear in court, be more interested in their welfare, and will be more positive when interacting with them. The judge will engage with the defendant, listening actively and communicating directly, often informally and more personally (Popovic, 2002; Winick, 2002-2003; King, 2003, 2006; Satel, 1998). In discussing the defendant's problems, the judge should 'communicate a sense of caring, sympathy, genuineness and understanding' (Winick, 2002-2003, p. 1069).

While therapeutic jurisprudence practices of judicial interaction overlap with those espoused for procedural justice, therapeutic jurisprudence is not simply about making people feel that justice has

\footnotetext{
${ }^{7}$ Although the discussion here focuses on problem-solving courts in the criminal law context, they may also operate in areas of civil law, such as the Family Drug and Alcohol Courts (FDAC) currently being rolled out in England and Wales, which seek to address the addiction problems and related parenting deficits of parents at risk of having children taken into care. See Harwin et al., 2014.
} 
been done, or that they have been listened to, and will therefore be more accepting of legal outcomes. Rather, procedural justice is seen as instrumental to the achievement of therapeutic goals. If defendants are treated with dignity and respect and given a sense of voice and validation, it is thought they will comply more willingly with treatment programs and be more likely to choose healthy behaviours (Winick 2002-2003, pp. 1088-1089; Wiener et al., 2010, pp. 422-423). The focus remains on encouraging individuals to address the root causes of offending - drug addiction, mental illness, violence and other psycho-social problems - and thereby enabling them to change their behaviour, in response to the positive, direct relationship with the judicial officer.

\section{Feminist judging}

\section{Philosophy}

It is more difficult to articulate a philosophy of feminist judging than it is to do so for procedurally just judging and therapeutic jurisprudence. First, unlike procedural justice and therapeutic jurisprudence, feminism is not primarily a theory of judging or a theory which has been developed in relation to judging. Feminism is a wider social theory and political practice which seeks to explain the causes of and to remedy women's disadvantages, inequalities, and subordination. Second, feminism is not unitary. There are multiple feminisms providing different answers to these questions. Thus, there is also the possibility of varying approaches among feminist judges (see Hunter et al., 2010).

Taking all this together, we would identify the basic philosophy of feminist judging as being to achieve gender justice, to the extent possible within the constraints of the judicial role. Many feminist judges are also concerned to achieve justice for other traditionally excluded groups (Hunter, 2008a). ${ }^{8}$ This philosophy is based on the understanding that law does not currently provide equal justice for all, that it is not in fact neutral and objective, but demonstrates a persistent bias towards the experiences, perspectives and interests of privileged white men. The role of a feminist judge is therefore to achieve justice by being alert to the ways in which apparently neutral or objective legal rules and practices may impact differently on women and men (Bartlett, 1990), and by acknowledging and incorporating, where relevant, the experiences, perspectives and interests of women and other traditionally excluded groups into decision-making (Boyle, 1985; Douglas et al., 2014a; Graycar, 1995; Hunter, 2008a, 2010, 2013; L'Heureux-Dubé, 1997). This may be based on the judicial officer's knowledge of women's and 'other' lives, and of the historic and systemic disadvantages experienced by women and other traditionally excluded groups. At the same time, the feminist judge will be aware of the limits of her own knowledge (Lawrence, 2004),

${ }^{8}$ It is acknowledged that not all feminisms are concerned with other axes of power such as race, class, colonialism and sexuality, but these differences are often jurisdictional, with 'radical' legal feminism having more purchase in the United States and in some international fora than elsewhere (see Valverde, 2015, ch. 4). 
and will be open to wider evidence and to hearing and trying to comprehend perspectives and experiences far removed from her own. Feminist judging may also be based, at least implicitly, on feminist theoretical knowledge, such as knowledge about the dynamics of abusive relationships, the objectification of women, the gender division of labour, the gendered effects of the public/private divide, the difference between formal and substantive equality, the feminisation of poverty, rape myths, feminist theories of sexual, reproductive and relational autonomy, intersectionality and so forth (Hunter et al., 2010).

Notably, feminist judging has substantive rather than simply procedural goals. It aims to achieve gender justice in the outcomes of cases as well as in the process of judging, and to consider the effects of decisions on broader social relationships. At the same time, there are many aspects of the process of judging which may be susceptible to a feminist approach.

\section{Practices}

In the process of hearing evidence and analysing facts, it has been argued that feminist judicial officers should engage in 'feminist practical reasoning' (Bartlett, 1990, pp. 849-850), that is, reasoning from context, focusing on the reality of women's lived experience in each situation, and producing a decision which considers the specific individual(s) before the court rather than relying on abstractions, generalisations or stereotypes. Contextualisation, as a feminist method, requires considering the specific situation of the parties, as well as the broader social context within which legal rules operate (Hunter, 2008a; see also Hunter, 2010; Douglas et al., 2014b). In a criminal case, according to Helen O'Sullivan, the judge should take into account the particular circumstances of the accused, the accuser and the case, and should 'really look' at the parties before her, treating both the accused and the accuser as people with reason, emotion and vulnerabilities, and as worthy of equal respect and dignity (O'Sullivan, 2007). Similarly, Patricia Cain has offered the following feminist recasting of Judge Learned Hand's advice to judges:

When you listen as a judge, you must transcend your sense of self, so that you can really listen. Listen to the story that is being told. Do not prejudge it. Do not say this is not part of my experience. But listen in such a way as to make it part of your experience. Find some small part of your own self that is like the Other's story. Identify with the Other. Do not contrast. Only when you have really listened, and only then, should you judge (Cain, 1988, p. 1955).

Ensuring that the context is properly understood might include specifically ascertaining facts, such as a woman defendant's domestic situation, whether she is the primary carer of young children, and what the impact on the children would be of sending her to jail (Daly, 1989). 
In making assessments of credibility, a feminist judicial officer would challenge rather than rely upon stereotypical or biased assumptions about sexual, racial and other forms of difference in behaviour (Hunter, 2008a; cf. Elvin, 2010). Challenging gender bias and stereotypes may include rejecting 'stock stories' and myths about victims' reactions, and challenging prosecutors and defence lawyers who attempt to rely on such myths and stereotypes in building their cases, crossexamining witnesses and making submissions (Hunter, 2008a, 2010, 2013; Douglas et al., 2014b). Conversely, a feminist judicial officer's background understanding of women's lives and of feminist theory might make her more inclined to believe a witness's story, more understanding of a defendant's behaviour, more inclined to assess matters as serious, or more able to understand a victim's fear in the context of domestic violence (see, for example, Hale, 2001, 2007; Hunter, 2008a, 2013).

In lower courts, one of the key practices of a feminist judicial officer will be her management of the courtroom, including her own interactions with participants and her management of interactions between participants. A feminist judicial officer may (though will not necessarily) subscribe to and attempt to implement a feminist ethic of care, which is marked by a view of one's position in relation to others as connected, relational, caring, nurturing and responsible, as opposed to the abstract, distanced, disengaged and legalistic stance of the conventional ethic of justice (see Crock and Steer, 2014; Gilligan, 1982; Resnik, 1988; Sevenhuijsen, 1998; Sherry, 1986). The therapeutic judge, for example, is clearly expected to evince an ethic of care towards the offenders appearing before her (King, 2009) and some feminist judicial officers may share this approach.

A feminist judicial officer might also seek to manage the courtroom so as to provide a process which supports, affirms and validates - rather than minimises - the experiences of victims of violence, expressing support and sympathy, naming harm and impressing on perpetrators the unacceptability of violent behaviour (O'Shane, 1994; Ptacek, 1999; Resnik, 1988). More generally, a feminist magistrate might seek to manage the courtroom so as to provide a process that minimises trauma for victims of crime (Martin, 1989; Hale, 2007; Hunter, 2008a), which might include enforcing available protections for vulnerable witnesses (Easteal, 1998; Hale, 2007; Hunter, 2015b) or close supervision of cross-examination (Schultz, 2001). As Hale has noted:

... properly protecting the prosecution witnesses while allowing the defence properly to deploy its case is a hugely demanding task. It is so much easier to sit back and let defence counsel rip. ... Enabling all the witnesses, on either side, to give their best evidence is a much more radical idea than you might think (Hale, 2007, p. 24).

In summary, while feminist judicial officers in the lower courts, by contrast with appellate judges, may have limited scope to take a critical approach to legislation or legal doctrine, there are a range of ways in which they may implement a feminist approach in the process of fact-finding, in their interactions with defendants and witnesses, and in their management of the courtroom to provide a fair and just experience for all participants. As noted earlier, the lower courts are most likely to deal 
with women defendants and gendered subject-matter such as domestic violence, and so the possibilities for feminist judging may be much greater than in higher courts.

\section{Comparing conventional, procedural justice, therapeutic and feminist judging}

These four approaches to judging involve differences in judicial philosophy as well as different judicial practices, though there is also considerable overlap between them. While all are concerned with core values of neutrality, impartiality and fair procedures, the three newer approaches to judging grow out of critiques of conventional judging. Common goals of the newer forms of judging, which contrast with conventional judging, are to 'address the whole person, not simply a depersonalised offender' (King et al., 2009, p. 83) and to 'consider the effects ... [of the legal process] on people in court' (Goldberg, 2005, p. 3). However these new approaches also differ in the nature and extent of their divergence from conventional judging.

\section{Philosophy}

The four approaches posit different goals for the judicial process. In conventional judging, the aim is to achieve and project legal legitimacy from the internal perspective of the legal system, through the impartial application of legal rules. Procedural justice is also concerned with legal legitimacy, but from an external perspective - that of the litigant. Procedural justice argues that court users are more likely to attribute legitimacy to a system which treats them with respect and dignity and makes them feel they have been heard. Therapeutic jurisprudence focuses instead on the capacity of law to do good rather than harm, to enhance the personal wellbeing of court users, and in particular, to address the root causes of offending behaviour and thereby to cure rather than merely punish the offender. By contrast, the substantive goal of feminist judging is to achieve gender or wider social justice, a goal which has potentially broader impacts than reforming individual offenders. At the same time, and unlike the other three approaches, feminist judging may not be applicable in every case, but only in those where an issue of gender or wider social justice arises. Moreover, feminist judging is constrained by the demands of (internal) legitimacy. A feminist judicial officer cannot pursue gender justice in disregard of the law, but may only do so within the limits of the law, such as through the legitimate exercise of discretion, assessment of evidence and management of the courtroom and the proceedings (Hunter, 2008a, 2010, 2015b).

The different philosophical underpinnings of the four approaches result in different views of substantive law, different ethical orientations, different focuses of attention, and different views of criminal defendants. Neither conventional judging nor procedural justice tend to question 
substantive legal rules: they are simply the rules which must be applied, according to thinner or thicker conceptions of procedural justice. The exception to this may be a resistance within conventional judging to rules which are perceived to unduly limit judicial discretion (such as mandatory sentencing provisions), to contravene 'fundamental' common law principles, or to offend judicial 'common sense' (Fielding, 2011; Hunter, 2015b). Therapeutic jurisprudence in its full sense does not so much question legal rules as work around them. Criminal punishment is suspended while the offender undergoes the treatment regime, but if she or he fails to complete the course, the punishment regime is reinstated with full force. Feminist judging, on the other hand, may, at higher levels of the court hierarchy, involve changing legal rules to achieve more just results for women and other outsiders. In the lower courts, however, while there is no scope for changing rules, there may be scope for criticising them and working for reform (Roach Anleu and Mack, 2007). At the same time, feminist judicial officers may be concerned fully to implement progressive laws designed to achieve gender or wider social justice, such as laws on discrimination, domestic violence and protections for vulnerable witnesses (Hunter, 2015b).

In terms of ethical orientations, conventional judging employs the traditional ethic of justice, which abstracts the issues and typically resolves conflicts by resort to a hierarchy of rights. Procedural justice and therapeutic jurisprudence might be seen, by contrast, to implement an ethic of care, in that the judicial officer seeks to establish a relationship with the parties, engages with them directly, and takes responsibility for their experience of the process (in the case of procedural justice) or for their wellbeing (in the case of therapeutic judging). Indeed, therapeutic jurisprudence in problemsolving courts relies on the judge developing an ongoing personal relationship of honesty, trust and rapport with the offender. Feminist judging may or may not involve an ethic of care: An ethic of care is certainly consistent with feminist judging, but its absence does not belie a feminist approach.

The focus of conventional judging is on the law and the judicial role. Litigants are regarded in abstract, categorical terms; thus a defendant in criminal proceedings is someone whose personal circumstances may only be relevant to the extent that they may operate as aggravating or mitigating factors in the sentencing calculus. The focus of procedural justice in a criminal matter, on the other hand, is on the dignity of the defendant, who is regarded as a subject who deserves to feel included, heard and understood, and whose experience of the judicial process matters, whatever the result may be. Therapeutic jurisprudence focuses on the defendant's welfare and psychological wellbeing. She or he is regarded as an individual situated in unfortunate circumstances, who has the capacity to work to change his or her life. Therapeutic jurisprudence is about developing the moral self as indicated by compliance with the treatment regime, assisted by advice, guidance, motivation and inspiration from the judge and the interdisciplinary experts. Like therapeutic jurisprudence, feminist judging sees the defendant as an individual situated in a particular context, but it lacks therapeutic jurisprudence's moral goals. Feminist judging sees the problems for individuals before the court as located in law and in society - i.e. as political, the product of systemic power differentials - rather than in the offender's personal choices, and thus it 
is more likely to seek empowerment for those who have been disempowered rather than individual moral reform. Its focus is also broader, taking in not only the defendant but also the victim, ${ }^{9}$ family members, and the wider social, cultural and economic context.

There is scope for overlap between feminist judging, procedural justice and therapeutic jurisprudence, in that feminist judging may incorporate a procedurally just approach (while incorporating other feminist elements as well), and feminist judicial officers may incorporate therapeutic goals and practices. For example, in Australia, some feminist magistrates sit in specialist domestic violence courts, and have also been involved in the establishment of other problem-solving courts such as drug courts and Koori/Murri courts (see, for example, Auty, 2006; Hennessy, 2007; Hunter, 2004; King and Auty, 2005; Previtera, 2006). But a feminist judicial officer with a therapeutic orientation may also be aware of the dangers of trying to be too interventionist or maternalist and thinking that she and the experts know best, rather than acknowledging and validating the defendant's expertise in her own life.

\section{Practice}

At the level of practice, while it should be possible to distinguish between more conventional and newer approaches to judging, it may be difficult to distinguish among the latter. For example, a key performance element in the newer approaches to judging is more direct judicial interaction with court users, as opposed to the detachment of conventional judging. This entails treating those before the courts with respect and dignity, acknowledging them as individuals rather than as a type, being concerned about their welfare, explaining the process, actively interacting with and listening to participants, engaging in direct dialogue with them and being less formal and impersonal than more traditionally-oriented judicial officers (King et al., 2014; Mack and Roach Anleu, 2011). This will require different judicial communication skills and perhaps greater emotional capacities such as empathy and compassion (Henderson, 1987; see also Acorn, 2004; Avgoustinos, 2007; Bandes, 2009; Massaro, 1989). At the same time, it may be difficult to tell whether the philosophy behind these practices is procedural justice, therapeutic jurisprudence or feminism.

Potentially the only way to distinguish between procedural justice and feminist judicial practices would be by reference to the context and content of the judicial performance. If the judge actively engaged with all defendants without more, that would appear to be a procedural justice approach. If the judge took a holistic view of the situation of all defendants and attempted to identify and address underlying problems, that would appear to be a therapeutic jurisprudence approach. If the

\footnotetext{
${ }^{9}$ Therapeutic jurisprudence might also, in theory, be concerned with law's therapeutic or anti-therapeutic effects on victims, however the therapeutic jurisprudence literature tends not to focus on victims and when it does, suggests that it is the responsibility of other parts of the criminal justice system, such as police and prosecutors, rather than judges, to take responsibility for victim wellbeing (for example Winick, 20082009).
} 
case involved a woman defendant or complainant or otherwise involved a gender or feminist issue, and the judge took steps to protect the complainant and/or affirm her experience, to understand the defendant's particular circumstances, to condemn male violence, and/or to combat gender stereotypes, that would appear to be a feminist approach.

Table 1 summarises the similarities and differences identified in this section.

< Table 1 about here >

\section{Conclusion}

These accounts of approaches to judging in the lower courts demonstrate that feminist judging clearly differs from other approaches to judging, but in ways which may be difficult to discern in terms of observable judicial performance. Therapeutic jurisprudence and feminism have most in common in terms of embracing substantive goals, taking a more critical view of law, (potential) deployment of the ethic of care, and judicial engagement, compassion and empathy. Both appear to incorporate procedural justice but go beyond it. However, therapeutic jurisprudence is still individualistic and moralistic, while feminist judging takes a more structural view. On the other hand, therapeutic jurisprudence in the sense of promoting participants' wellbeing and minimising the harms caused by the legal system, is arguably applicable to a wide range of cases, whereas feminist judging might be more limited in scope.

This is not to suggest that, because of their substantive goals, therapeutic jurisprudence and feminist judging as practices in the lower courts risk violating norms of judicial decision-making. Fidelity to judicial legitimacy, understood as impartiality, neutrality, application of law and following legal procedures, remains central to all approaches to judging in courts at all levels, and indeed, the conventional approach to implementing these values exerts considerable 'gravitational pull' over all approaches to judging. ${ }^{10}$ However, newer forms of judging challenge the assumption in conventional judging philosophy that these values can only be performed in specific, limited ways. Indeed, proponents of feminist judging have argued that a feminist approach is likely to be more fair and truly impartial than conventional judging, because it overcomes conventional partiality towards masculine experience and perspectives (Hale, 2007; Hunter, 2008a, 2015b).

This article provides a detailed analysis and comparison of ways the four approaches to judging might manifest in lower court practice as 'ideal types', but these distinctions may not be so sharp or so readily perceptible in actual courtroom processes. Versions of procedural justice and therapeutic jurisprudence might be weak or minimal. Implementation of philosophical ideals may be inconsistent, perhaps due to the constraints of the forum, the type of matter and/or the way

10 We are grateful to Professor Margaret Davies for the suggestion of the metaphor of 'gravitational pull' in this context (see also Cooper, 2001). 
participants interact with the judge. Judicial philosophies may be more or less consciously pursued. Nonetheless, conceptually differentiating these four approaches to judging in the lower court context, and identifying key similarities and differences, provides an essential foundation on which to further specify and extend understandings of the scope and nature of feminist judging beyond the higher courts. 
Table 1: Comparing approaches to judging

\begin{tabular}{|c|c|c|c|c|}
\hline Dimensions & Conventional & $\begin{array}{l}\text { Procedural } \\
\text { Justice Judging }\end{array}$ & $\begin{array}{l}\text { Therapeutic } \\
\text { Judging }\end{array}$ & Feminist Judging \\
\hline Objective & $\begin{array}{l}\text { Legal } \\
\text { legitimacy, from } \\
\text { the point of view } \\
\text { of the legal } \\
\text { system }\end{array}$ & $\begin{array}{l}\text { Legal legitimacy, } \\
\text { from the point of } \\
\text { view of litigants }\end{array}$ & $\begin{array}{l}\text { Enhance wellbeing, } \\
\text { address underlying } \\
\text { problems }\end{array}$ & $\begin{array}{l}\text { Gender/social } \\
\text { justice }\end{array}$ \\
\hline Scope & All cases & All cases & $\begin{array}{l}\text { Full version: } \\
\text { problem solving } \\
\text { courts, diversion } \\
\text { programs. More } \\
\text { limited version in } \\
\text { all cases }\end{array}$ & $\begin{array}{l}\text { Cases raising } \\
\text { issues of } \\
\text { gender/social } \\
\text { justice }\end{array}$ \\
\hline $\begin{array}{l}\text { View of } \\
\text { substantive law }\end{array}$ & $\begin{array}{l}\text { Generally } \\
\text { uncritical; critical } \\
\text { of legislative } \\
\text { interventions } \\
\text { which encroach } \\
\text { on judicial } \\
\text { discretion or } \\
\text { defy 'common } \\
\text { sense' }\end{array}$ & $\begin{array}{l}\text { Generally } \\
\text { uncritical }\end{array}$ & $\begin{array}{l}\text { Generally critical; } \\
\text { at best only part of } \\
\text { the solution. May } \\
\text { need to be by- } \\
\text { passed in order to } \\
\text { address problems }\end{array}$ & $\begin{array}{l}\text { Critical of laws } \\
\text { creating } \\
\text { gender/social } \\
\text { injustice; } \\
\text { supportive of laws } \\
\text { designed to } \\
\text { address harms to } \\
\text { women/other } \\
\text { excluded groups }\end{array}$ \\
\hline Ethics & $\begin{array}{l}\text { Justice/rights - } \\
\text { responsible for } \\
\text { administration of } \\
\text { law }\end{array}$ & $\begin{array}{l}\text { Justice/rights and } \\
\text { care; responsible } \\
\text { for administration } \\
\text { of law and for } \\
\text { participants' } \\
\text { experience of the } \\
\text { process }\end{array}$ & $\begin{array}{l}\text { Care; responsible } \\
\text { for participants' } \\
\text { wellbeing }\end{array}$ & $\begin{array}{l}\text { Care? } \\
\text { Responsible for } \\
\text { remedying } \\
\text { inequalities, } \\
\text { injustice or } \\
\text { exclusion; } \\
\text { understanding } \\
\text { and validating } \\
\text { marginalised } \\
\text { experience as far } \\
\text { as possible }\end{array}$ \\
\hline Focus & Law/judicial role & $\begin{array}{l}\text { Dignity of parties/ } \\
\text { defendant }\end{array}$ & $\begin{array}{l}\text { Welfare/ } \\
\text { psychological well- } \\
\text { being of defendant }\end{array}$ & $\begin{array}{l}\text { Impacts of law on } \\
\text { defendants, } \\
\text { victims, and the } \\
\text { wider community } \\
\text { (esp in cases } \\
\text { raising issues of } \\
\text { gender/social } \\
\text { justice) }\end{array}$ \\
\hline $\begin{array}{l}\text { View of } \\
\text { defendant }\end{array}$ & $\begin{array}{l}\text { Abstract/ } \\
\text { Categorical }\end{array}$ & Individual & $\begin{array}{l}\text { Situated in } \\
\text { destructive } \\
\text { behaviour patterns } \\
\text { which defendants } \\
\text { can choose to } \\
\text { change }\end{array}$ & $\begin{array}{l}\text { Situated in a } \\
\text { gendered social } \\
\text { context }\end{array}$ \\
\hline Judicial & Detached, & Engaged, & Engaged, & Engaged, \\
\hline
\end{tabular}




\begin{tabular}{|l|l|l|l|l|}
\hline approach & $\begin{array}{l}\text { impersonal, } \\
\text { formal, } \\
\text { authoritative }\end{array}$ & $\begin{array}{l}\text { relational, } \\
\text { less formal }\end{array}$ & $\begin{array}{l}\text { relational, } \\
\text { less formal, } \\
\text { authoritative }\end{array}$ & $\begin{array}{l}\text { relational, } \\
\text { less formal }\end{array}$ \\
\hline $\begin{array}{l}\text { Judicial qualities } \\
\text { (in addition to } \\
\text { legal knowledge } \\
\text { and application } \\
\text { and } \\
\text { commitment to } \\
\text { impartiality, } \\
\text { neutrality) }\end{array}$ & $\begin{array}{l}\text { Sound } \\
\text { judgment, } \\
\text { courtesy, } \\
\text { patience }\end{array}$ & $\begin{array}{l}\text { Respect for } \\
\text { participants, } \\
\text { listening and } \\
\text { responding, }\end{array}$ & $\begin{array}{l}\text { Compassion, } \\
\text { empathy, welfare } \\
\text { orientation, } \\
\text { problem-solving } \\
\text { orientation, multi- } \\
\text { disciplinary } \\
\text { teamwork }\end{array}$ & $\begin{array}{l}\text { Compassion, } \\
\text { empathy; } \\
\text { understanding of } \\
\text { women's lives, } \\
\text { histories of } \\
\text { exclusion; } \\
\text { feminist } \\
\text { knowledge, } \\
\text { openness to } \\
\text { different } \\
\text { perspectives }\end{array}$ \\
\hline
\end{tabular}




\section{References}

ACORN, A. E. (2004) Compulsory Compassion: A Critique of Restorative Justice. Vancouver: UBC Press.

AMERICAN BAR ASSOCIATION (2007) Model Code of Judicial Conduct, online: $<$ http://www.abanet.org/judicialethics/ABA_MCJC_approved.pdf> (last accessed 15 April 2008).

ANNISON, H. (2014) 'Interpreting the Politics of the Judiciary: The British Senior Judicial Tradition and the Pre-Emptive Turn in Criminal Justice', Journal of Law and Society 41(3): 339-366.

AUSTRALASIAN INSTITUTE OF JUDICIAL ADMINISTRATION. (2002) Guide to Judicial Conduct. Carlton: Australian Institute of Judicial Administration.

AUSTRALASIAN INSTITUTE OF JUDICIAL ADMINISTRATION (2015) Judicial Gender Statistics, online: <http://www.aija.org.au/index.php/judicial-gender-statistics> (last accessed 20 March 2015).

AUSTRALIAN GOVERNMENT PRODUCTIVITY COMMISSION (2015) 'Report on Government Services: Court Administration (Chapter 7)', Canberra: Steering Committee for the Review of Government Service Provision.

AUSTRALIAN LAW REFORM COMMISSION (2000) 'Managing Justice: A Review of the Federal Civil Justice System', Report No 89. Canberra: Australian Law Reform Commission.

AUSTRALIAN LAW REFORM COMMISSION (2006) 'Same Crime, Same Time: Sentencing of Federal Offenders', Report No 103. Sydney: Australian Law Reform Commission.

AUTY, K. (2006) 'We Teach All Hearts to Break but Can We Mend Them? Therapeutic Jurisprudence and Aboriginal Sentencing Courts', Murdoch University Electronic Journal of Law, eLaw Journal (special series) 1: 101.

AVGOUSTINOS, C. (2007) 'The Compassionate Judge', The Journal of Law and Social Justice 1 (Article 7): 1-41.

BAINES, B. (2013) 'Must Feminist Judges Self-Identify as Feminists?', in U. Schultz and G. Shaw (eds), Gender and Judging. Oxford and Portland, OG: Hart Publishing.

BAKER, T. E. (1994) Rationing Justice on Appeal: The Problems of the U.S. Courts of Appeals. Eagan, MN.: West Publishing.

BANDES, S. A. (2009) 'Empathetic Judging and the Rule of Law', Cardozo Law Review De Novo: 133-148.

BARTELS, L. (2009) 'Challenges in Mainstreaming Specialty Courts', Trends \& Issues in Crime and Criminal Justice. Canberra: Australian Institute of Criminology.

BARTLETT, K. T. (1990) 'Feminist Legal Methods', Harvard Law Review 103(4): 829-888.

BEAN, P. (2002) 'Drug Courts, the Judge, and the Rehabilitative Ideal', in J. L. Nolan (ed), Drug Courts in Theory and in Practice. New York, NY: Aldine de Gruyter.

BERMAN, G. (2000) 'What Is a Traditional Judge Anyway? Problem Solving in the State Courts', Judicature 84(2): 78-85.

BERMAN, G. and FEINBLATT, J. (2001) 'Problem-Solving Courts: A Brief Primer', Law \& Policy 23(2): 125-140.

BEZDEK, B. (1992) 'Silence in the Court: Participation and Subordination of Poor Tenants' Voices in Legal Process', Hofstra Law Review 20(3): 533-608.

BOLTON, E. (2012) 'The Magistrates Court Trial', in T. Gray, M. Hinton and D. Caruso (eds), Essays in Advocacy. Adelaide: Barr Smith Press.

BOROWSKI, A. (2013) 'Whither Australia's Children's Courts? Findings of the National Assessment of Australia's Children's Courts', Australian \& New Zealand Journal of Criminology 46(2): 268-288. 
BOYLE, C. (1985) 'Sexual Assault and the Feminist Judge', Canadian Journal of Women and Law 1(1): 93-107.

BRAITHWAITE, J. (1989) 'The State of Criminology: Theoretical Decay or Renaissance', Australian and New Zealand Journal of Criminology 22(3): 129-135.

BREMS, E. (ed) (2013) Diversity and European Human Rights: Rewriting Judgments of the ECHR. Cambridge: Cambridge University Press.

BURKE, K. and LEBEN, S. (2007-2008) 'Procedural Fairness: A Key Ingredient in Public Satisfaction'. Court Review 44(1/2): 4-5.

BURNS, S. L. and PEYROT, M. (2003) 'Tough Love: Nurturing and Coercing Responsibility and Recovery in California Drug Courts', Social Problems 50(3): 416-438.

BYBEE, K. J. (2010) All Judges Are Political - except When They Are Not: Acceptable Hypocrisies and the Rule of Law. Stanford, CA: Stanford Law Books.

CAIN, P. A. (1988) 'Good and Bad Bias: A Comment on Feminist Theory and Judging', Southern California Law Review 61: 1945-1955.

CARLEN, P. (1976) Magistrates' Justice. London: Martin Robertson.

CASPER, J. D., TYLER, T. R. and FISHER, B. (1988) 'Procedural Justice in Felony Cases', Law \& Society Review 22(3): 483-507.

CHRISS, J. J. (2002) 'The Drug Court Movement: An Analysis of Tacit Assumptions', in J. L. Nolan (ed), Drug Courts in Theory and in Practice. New York, NY: Aldine de Gruyter.

COOPER, D. (2001) 'Against the Current: Social Pathways and the Pursuit of Enduring Change', Feminist Legal Studies 9: 119-148.

COURTS AND TRIBUNAL JUDICIARY (UK) (2014) Judicial Diversity Statistics 2014, online: $<$ https://www.judiciary.gov.uk/publications/judicial-diversity-statistics-2014/> (last accessed 20 March 2015).

COWAN, D., BLANDY, S., HITCHINGS, E., HUNTER, C. and NIXON, J. (2006) 'District Judges and Possession Proceedings', Journal of Law and Society 33(4): 547-571.

COWAN, D. and HITCHINGS, E. (2007) '"Pretty Boring Stuff"': District Judges and Housing Possession Proceedings', Social \& Legal Studies 16(3): 363-382.

CRAWFORD, J. and OPESKIN, B. (2004) Australian Courts of Law. Melbourne: Oxford University Press.

CROCK, M. and STEER, C. (2014) 'Re Minister for Immigration and Multicultural and Indigenous Affairs; Ex Parte Applicants S134/2002 [2003] HCA 1', in H. Douglas, F. Bartlett, T. Luker and R. Hunter (eds), Australian Feminist Judgments: Righting and Rewriting Law. Oxford and Portland, OG: Hart.

DALY, K. (1989) 'Rethinking Judicial Paternalism: Gender, Work-Family Relations, and Sentencing', Gender \& Society 3(1): 9-36.

DAVIES, M. (2012) 'The Law Becomes Us: Rediscovering Judgment', Feminist Legal Studies 20(2): 167-181.

DOUGLAS, H., BARTLETT, F., LUKER, T. and HUNTER, R. (eds) (2014a) Australian Feminist Judgments: Righting and Rewriting Law. Oxford and Portland, OG: Hart.

DOUGLAS, H., BARTLETT, F., LUKER, T. and HUNTER, R. (2014b) 'Reflections on Rewriting the Law', in H. Douglas, F. Bartlett, T. Luker and R. Hunter (eds), Australian Feminist Judgments: Righting and Rewriting Law. Oxford and Portland, OG: Hart.

DOUGLAS, R. N. and LASTER, K. (1992) 'Reforming the People's Court: Victorian Magistrates' Reactions to Change', Criminology Research Council Grant 13/90.

DOYLE, J. (2001) 'The Judicial Role in a New Millennium', Journal of Judicial Administration 10(3): 133-148. 
EASTEAL, P. (ed) (1998) Balancing the Scales: Rape, Law Reform and Australian Culture. Sydney: Federation Press.

EISENSTEIN, J., FLEMMING, R. B. and NARDULLI, P. F. (1988) The Contours of Justice: Communities and Their Courts. Boston: Little, Brown and Company.

ELVIN, J.D. (2010) 'The Continuing Use of Problematic Sexual Stereotypes in Judicial DecisionMaking, Feminist Legal Studies 18: 275-297.

EMERSON, R. (1969) Judging Delinquents. Chicago, IL: Aldine.

EMERSON, R. M. (1983) 'Holistic Effects in Social Control Decision-Making', Law and Society Review 17(3): 425-455.

EPSTEIN, L., LANDES, W. M. and POSNER, R. A. (2013) The Behavior of Federal Judges: A Theoretical and Empirical Study of Rational Choice. Cambridge, MA: Harvard University Press.

FAROLE, D. J. (2009) 'Problem Solving and the American Bench: A National Survey of Trial Court Judges', The Justice System Journal 30(1): 50-69.

FAROLE, D. J., PUFFETT, N., REMPEL, M. and BYRNE, F. (2005) 'Applying the Problem-Solving Model Outside of Problem-Solving Courts', Judicature 89(1): 40-42.

FIELDING, N. G. (2011) 'Judges and Their Work', Social \& Legal Studies 20(1): 97-115.

FISS, O. M. (1983) 'The Bureaucratization of the Judiciary', Yale Law Journa/92(July): 1442-1468.

FREIBERG, A. (2001) 'Problem-Oriented Courts: Innovative Solutions to Intractable Problems', Journal of Judicial Administration 11(1): 8-27.

FREIBERG, A. (2007) 'Non-Adversarial Approaches to Criminal Justice', Journal of Judicial Administration 16: 205-222.

GARFINKEL, H. (1956) 'Conditions of Successful Degradation Ceremonies', American Journal of Sociology 61(5): 420-424.

GIBSON, J. L. (1980) 'Environmental Constraints of the Behavior of Judges: A Representational Model of Judicial Decision Making', Law \& Society Review 14(2): 343-370.

GILLIGAN, C. (1982) In a Different Voice: Psychological Theory and Women's Development. Cambridge, MA: Harvard University Press.

GLEESON, A. M. (1998) 'Performing the Role of the Judge', Judicial Officers Bulletin 10(8): 57-60.

GLEESON, M. (2010) 'The Judicial Method: Essentials and Inessentials', Judicial Review 9(4): 377-388.

GOFFMAN, E. (1955) 'On Face-Work: An Analysis of Ritual Elements in Social Interaction', Psychiatry: Interpersonal and Biological Processes 18(3): 213-231.

GOLDBERG, S. (2005) 'Judging for the 21st Century: A Problem-Solving Approach', Ottowa: National Judicial Institute.

GRAYCAR, R. (1995) 'The Gender of Judgments: An Introduction', in M. Thornton (ed), Public and Private: Feminist Legal Debates. Melbourne: Oxford University Press.

HALE, B. (2001) 'Equality and the Judiciary: Why Should We Want More Women Judges?', Public Law [2001](Autumn): 489-504.

HALE, B. (2007) 'Maccabaean Lecture in Jurisprudence: A Minority Opinion?', in R. Johnston (ed), Proceedings of the British Academy, Volume 154, 2007. London: British Academy.

HARWIN, J., ALROUH, B., RYAN, M. and TUNNARD, J. (2014) 'Changing Lifestyles, Keeping Children Safe: An Evaluation of the First Family Drug and Alcohol Court (FDAC) in Care Proceedings', London: Brunel University.

HEIMER, C. A. (2001) 'Cases and Biographies: An Essay on Routinization and the Nature of Comparison', Annual Review of Sociology 27: 47-76. 
HENDERSON, L. N. (1987) 'Legality and Empathy', Michigan Law Review 85: 1574-1653.

HENNESSY, A. (2007) 'Reconnection to Community as a Sentencing Tool', in G. Reinhardt and A. J. Cannon (eds), Transforming Legal Processes in Court and Beyond: A Collection of Refereed Papers from the 3rd International Conference on Therapeutic Jurisprudence. Perth: Australian Institute of Judicial Administration.

HEYDON, J. D. (2012) 'Varieties of Judicial Method in the Late 20th Century', Judicial Review 10(4): 375-398.

HOCHSCHILD, A. R. (1983) The Managed Heart: Commercialization of Human Feeling. Berkeley, CA: University of California Press.

HORA, P. F., SCHMA, W. G. and ROSENTHAL, J. T. A. (1999) 'Therapeutic Jurisprudence and the Drug Treatment Court Movement: Revolutionizing the Criminal Justice System's Response to Drug Abuse and Crime in America', Notre Dame Law Review 74: 439-537.

HUNTER, C., NIXON, J. and BLANDY, S. (2008) 'Researching the Judiciary: Exploring the Invisible in Judicial Decision Making ', Journal of Law and Society 35(1): 76-90.

HUNTER, R. (2004) 'Fear and Loathing in the Sunshine State', Australian Feminist Studies 19(44): 145-157.

HUNTER, R. (2005) 'Styles of Judging: How Magistrates Deal with Applications for Intervention Orders', Alternative Law Journa/30(5): 231-236, 246.

HUNTER, R. (2008a) 'Can Feminist Judges Make a Difference?', International Journal of the Legal Profession 15(1-2): 7-36.

HUNTER, R. (2008b) Domestic Violence Law Reform and Women's Experience in Court: The Implementation of Feminist Reforms in Civil Proceedings. Amherst, New Yorkn NY: Cambria Press.

HUNTER, R. (2010) 'An Account of Feminist Judging', in R. Hunter, C. Mcglynn and E. Rackley (eds), Feminist Judgments: From Theory to Practice. Oxford and Portland, OG: Hart Publishing.

HUNTER, R. (2012a) 'Feminist Judgments as Teaching Resources', Oñati Socio-Legal Series 2(5): 47-62.

HUNTER, R. (2012b) 'The Power of Feminist Judgments?', Feminist Legal Studies 20(2): 135-148.

HUNTER, R. (2013) 'Justice Marcia Neave: Case Study of a Feminist Judge', in U. Schultz and G. Shaw (eds), Gender and Judging. Oxford and Portland, OG: Hart Publishing.

HUNTER, R. (2015a) 'Feminist Judgments Projects: Legal Fiction as Critique and Praxis', International Critical Thought 5: 501-508.

HUNTER, R. (2015b) 'More than Just a Different Face? Judicial Diversity and Decision-making', Current Legal Problems (forthcoming). DOI: 10.1093/clp/cuv001.

HUNTER, R., MCGLYNN, C. and RACKLEY, E. (eds) (2010) Feminist Judgments: From Theory to Practice. Oxford: Hart Publishing.

INTLAWGRRLS (2014) Invitation to Participate in the Feminist International Judgments Project, online: <http://ilg2.org/2014/01/16/invitation-to-participate-in-the-feminist-internationaljudgments-project/> (last accessed 1 April 2015).

JUDICIAL APPOINTMENT COMMISSION (UK) Recorder Competency Framework, online: $<$ https://jac.judiciary.gov.uk/800-recorder-competency-framework> (last accessed 1 May 2015).

JUDICIAL APPOINTMENTS BOARD FOR SCOTLAND Judicial Qualities, online: <http://www.judicialappointmentsscotland.org.uk/Guide_to_Appointment_Process/Judicial_ Qualities> (last accessed 1 May 2015).

KING, M. (2003) 'Applying Therapeutic Jurisprudence from the Bench', Alternative Law Journal 28(4): 172-175. 
KING, M. (2006) 'The Therapeutic Dimensions of Judging: The Example of Sentencing', Journal of Judicial Administration 16(2): 92-105.

KING, M. (2008) 'Restorative Justice, Therapeutic Jurisprudence and the Rise of Emotionally Intelligent Justice', Melbourne University Law Review 32: 1096-1126.

KING, M. (2009) Solution-Focused Judging Bench Book. Melbourne: Australasian Institute of Judicial Administration.

KING, M. and AUTY, K. (2005) 'Therapeutic Jurisprudence: An Emerging Trend in Courts of Summary Jurisdiction', Alternative Law Journa/30(2): 69-73.

KING, M. and FORD, S. (2006) 'Exploring the Concept of Wellbeing in Therapeutic Jurisprudence: The Example of the Geraldton Alternative Sentencing Regime', Murdoch University Electronic Journal of Law, eLaw Journal (special series) 1: 9.

KING, M., FREIBERG, A., BATAGOL, B. and HYAMS, R. (2009) Non-Adversarial Justice. Annandale, NSW: Federation Press.

KING, M., FREIBERG, A., BATAGOL, B. and HYAMS, R. (2014) Non-Adversarial Justice. Annandale: Federation Press.

KING, M. and WAGER, J. (2005) 'Therapeutic Jurisprudence and Problem-Solving Judicial Case Management', Journal of Judicial Administration 15(1): 28-36.

L'HEUREUX-DUBÉ, C. (1997) 'Making a Difference: The Pursuit of a Compassionate Justice', University of British Columbia Law Review 31(1): 1-15.

LAWRENCE, S. (2004) 'Feminism, Counsequences, Accountability', Osgoode Hall Law Journal 42(2): 583-601.

LEE, H. P. and CAMPBELL, E. (2013) The Australian Judiciary. New York, NY: Cambridge University Press.

LENS, V. (2012) 'Judge or Bureaucrat? How Administrative Law Judges Exercise Discretion in Welfare Bureaucracies', Social Service Review 86(2): 269-293.

LIND, E. A. and TYLER, T. R. (1988) The Social Psychology of Procedural Justice. New York, NY and London: Plenum Press.

LIPSKY, M. (2010) Street-Level Bureaucracy: Dilemmas of the Individual in Public Service. New York, NY: Russell Sage Foundation.

LITHWICK, D. (2009). 'What a Waste', Slate, online: < http://slate.com/id/2222936/> (last updated 21 August 2009).

MACCOUN, R. J. (2005) 'Voice, Control, and Belonging: The Double-Edged Sword of Procedural Fairness', Annual Review of Law and Social Science 1(1): 171-201.

MACK, K. and ROACH ANLEU, S. (2007) "'Getting through the List": Judgecraft and Legitimacy in the Lower Courts', Social \& Legal Studies 16(3): 341-361.

MACK, K. and ROACH ANLEU, S. (2010) 'Performing Impartiality: Judicial Demeanor and Legitimacy', Law \& Social Inquiry 35(1): 137-173.

MACK, K. and ROACH ANLEU, S. (2011) 'Opportunities for New Approaches to Judging in a Conventional Context: Attitudes, Skills and Practices', Monash University Law Review 37(1): 187-215.

MACK, K. and ROACH ANLEU, S. (2012) 'In-Court Judicial Behaviours, Gender and Legitimacy', Griffith Law Review 21(3): 728-751.

MACK, K., WALLACE, A. and ROACH ANLEU, S. (2012) Judicial Workload: Time, Tasks and Work Organisation. Melbourne: Australasian Institute of Judicial Administration.

MACKENZIE, G. (2005) How Judges Sentence. Annandale: Federation Press.

MACKENZIE, G., STOBBS, N. and O'LEARY, J. (2010) Principles of Sentencing. Sydney: Federation Press. 
MAJURY, D. (2006) 'Introducing the Women's Court of Canada', Canadian Journal of Women and the Law 18: 1.

MALLESON, K. (1999) The New Judiciary: The Effects of Expansion and Activism. Dartmouth: Aldershot.

MARONEY, T. A. (2011a) 'Emotional Regulation and Judicial Behavior', California Law Review 99(2): 1485-1555.

MARONEY, T. A. (2011b) 'The Persistent Cultural Script of Judicial Dispassion', California Law Review 99: 629-82.

MARONEY, T. A. and GROSS, J. J. (2014) 'The Ideal of the Dispassionate Judge: An Emotion Regulation Perspective', Emotion Review6(2): 142-151.

MARTIN, E. (1989) 'Differences in Men and Women Judges: Perspectives on Gender', Journal of Political Science 17: 74-85.

MASSARO, T. M. (1989) 'Empathy, Legal Storytelling, and the Rule of Law: New Words, Old Wounds?', Michigan Law Review 87(8): 2099-2127.

MATHER, L. M. (1979) Plea Bargaining or Trial? The Process of Criminal-Case Disposition. Lexington, MA: Lexington Books.

MCCOY, C. (1997) 'Sentencing (and) the Underclass', Law and Society Review 31(3): 589.

MCIVOR, G. (2009) 'Therapeutic Jurisprudence and Procedural Justice in Scottish Drug Courts', Criminology \& Criminal Justice 9(1): 29-49.

MCMAHON, M. and WEXLER, D. (2002) 'Therapeutic Jurisprudence: Developments and Applications in Australia and New Zealand', Law and Context Special Issue: Therapeutic Jurisprudence 20(2): 1-23.

MILESKI, M. (1971) 'Courtroom Encounters: An Observational Study of a Lower Criminal Court', Law \& Society Review 5(4): 473-538.

MOORE, D. (2007) 'Translating Justice and Therapy: The Drug Treatment Court Networks', British Journal of Criminology 47(1): 42-60.

MOORE, D., FREEMAN, L. and KRAWCZYK, M. (2011) 'Spatio-Therapeutics: Drug Treatment Courts and Urban Space', Social \& Legal Studies 20(2): 157-172.

MOORHEAD, R. (2007) 'The Passive Arbiter: Litigants in Person and the Challenge to Neutrality', Social and Legal Studies 16(3): 405-424.

MOORHEAD, R. and COWAN, D. (2007) 'Judgecraft: An Introduction', Social \& Legal Studies 16(3): 315-320.

MORAN, L. J. (2009) 'Judging Pictures: A Case Study of Portraits of the Chief Justices, Supreme Court of New South Wales', International Journal of Law in Context 5(3): 295-314.

MORAN, L. J. (2010) 'In Conversation with Lord Justice Etherton: Judicial Legitimacy, Diversity and the Representation of Judicial Authority', Public Law 4: 662-671.

MULCAHY, L. (2007) 'Architects of Justice: The Politics of Courtroom Design', Social and Legal Studies 16(3): 383-403.

MULCAHY, L. (2011) Legal Architecture: Justice, Due Process and the Place of Law. New York, NY: Routledge.

NEW ZEALAND LAW SOCIETY (2015) NZ Feminist Judgments Project Seeks Contributors, online: <https://www.lawsociety.org.nz/news-and-communications/latest-news/news/nzfeminist-judgments-project-seeks-contributors> (last accessed 21 January 2016).

NOLAN, J. L. (1998) The Therapeutic State: Justifying Government at Century's End. New York, NY: New York University Press.

NOLAN, J. L. J. (2003) 'Redefining Criminal Courts: Problem-Solving and the Meaning of Justice ', American Criminal Law Review 40(4): 1541-1565. 
NORTHERN/IRISH FEMINIST JUDGMENTS PROJECT (2015) About, online: $<$ http://www.feministjudging.ie/?p=6> (last accessed 20 March 2015).

NUSSBAUM, M. (1996) 'Emotion in the Language of Judging', St John's Law Review 70: 23-30.

O'BARR, W. M. and CONLEY, J. M. (1985) 'Litigant Satisfaction Versus Legal Adequacy in Small Claims Court Narratives', Law \& Society Review 19(4): 661-702.

O'SHANE, P. (1994) 'Launch of the Australian Feminist Law Journal', Australian Feminist Law Journa/2(1): 3-12.

O'SULLIVAN, H. (2007) 'The Right to Silence at Trial: A Critique and a Call for a New Approach.' PhD, Griffith University.

PHELAN, A. (2003) 'Solving Human Problems or Deciding Cases? Judicial Innovation in New York and Its Relevance to Australia: Part I', Journal of Judicial Administration 13(2): 98-130.

PHELAN, A. (2004) 'Solving Human Problems or Deciding Cases? Judicial Innovation in New York and Its Relevance to Australia: Part II', Journal of Judicial Administration 13(3): 137-181.

POPOVIC, J. (2002) 'Judicial Officers: Complementing Conventional Law and Changing the Culture of the Judiciary', Law in Context 20: 121-136.

PREVITERA, T. (2006) 'Responsibilities of TJ Team Members v Rights of Offenders', Murdoch University Electronic Journal of Law, eLaw Journal (special series) 1: 51.

PTACEK, J. (1999) Battered Women in the Courtroom: The Power of Judicial Responses. Boston, MA: Northeastern University Press.

RABINOW, P. and ROSE, N. (2006) 'Biopower Today', BioSocieties 1: 195-217.

RACKLEY, E. (2012) 'Why Feminist Legal Scholars Should Write Judgments: Reflections on the Feminist Judgments Project in England and Wales', Canadian Journal of Women and the Law 24(2): 389-413.

RESNIK, J. (1988) 'On the Bias: Feminist Reconsiderations of the Aspirations for Our Judges', Southern California Law Review 61: 1877-1944.

RESNIK, J. and CURTIS, D. E. (2011) Representing Justice : Invention, Controversy, and Rights in City-States and Democratic Courtrooms. New Haven, CT. ; London: Yale University Press.

RIEFF, P. (1966) The Triumph of the Therapeutic. London: Chatto \& Windus.

ROACH ANLEU, S. and MACK, K. (2005) 'Magistrates' Everyday Work and Emotional Labour', Journal of Law and Society 32(4): 590-614.

ROACH ANLEU, S. and MACK, K. (2007) 'Magistrates, Magistrates Courts and Social Change', Law \& Policy 29(2): 183-209.

ROACH ANLEU, S. and MACK, K. (2008) 'The Professionalization of Australian Magistrates: Autonomy, Credentials and Prestige ', Journal of Sociology 44(2): 185-203.

ROACH ANLEU, S. and MACK, K. (2009) 'Intersections between in-Court Procedures and the Production of Guilty Pleas', Australian \& New Zealand Journal of Criminology 42(1): 1-23.

ROACH ANLEU, S. and MACK, K. (2013a) 'Judicial Authority and Emotion Work', The Judicial Review 11: 329-347.

ROACH ANLEU, S. and MACK, K. (2013b) 'Performing Authority: Communicating Judicial Decisions in Lower Criminal Courts', Journal of Sociology. DOI: $10.1177 / 1440783313495765$.

ROACH ANLEU, S. and MACK, K. (2014) 'Judicial Performance and Experiences of Judicial Work: Findings from Socio-Legal Research', Oñati Socio-Legal Series 4(5): 1015-1040.

ROSE, N. (1993) 'Government, Authority and Expertise in Advanced Liberalism', Economy and Society 22(3): 283-299.

ROSE, N. and MILLER, P. (1992) 'Political Power Beyond the State: Problematics of Government', British Journal of Sociology 43(2): 173-205. 
ROSE, N., O'MALLEY, P. and VALVERDE, M. (2006) 'Governmentality', Annual Review of Law and Social Science 2: 83-104.

ROTTMAN, D. B. and TYLER, T. R. (2014) 'Thinking About Judges and Judicial Performance: Perspective of the Public and Court Users', Oñati Socio-Legal Series 4(5): 1046-1070.

SATEL, S. L. (1998) 'Observational Study of Courtroom Dynamics in Selected Drug Courts', National Drug Court Institute Review 1(1): 56-85.

SCHULTZ, J. (2001) 'Can Women Judges Help Make Civil Sexual Assault Trials More Therapeutic?', Wisconsin Women's Law Journal 16: 53-66.

SEVENHUIJSEN, S. (1998) Citizenship and the Ethics of Care: Feminist Considerations on Justice, Morality, and Politics. London and New York, NY: Routledge.

SHAMAN, J. M. (1996) 'The Impartial Judge: Detachment or Passion?', DePaul Law Review45: 605-632.

SHERRY, S. (1986) 'The Gender of Judges', Law and Inequality 4: 159-169.

SMITH, A. B. and BLUMBERG, A. S. (1967) 'The Problem of Objectivity in Judicial DecisionMaking', Social Forces 46(1): 96-105.

TAIT, D. (2002) 'Sentencing and Performance: Restoring Drama to the Courtroom', in C. Tata and N. Hutton (eds), Sentencing and Society: International Perspectives. Aldershot and Hampshire: Ashgate.

TAMANAHA, B. Z. (2010) Beyond the Formalist-Realist Divide: The Role of Politics in Judging. Princeton and Oxford: Princeton University Press.

TATA, C. (2007) 'Sentencing as Craftwork and the Binary Epistemologies of the Discretionary Decision Process', Social and Legal Studies 16(3): 425-447.

THOMAS, D. A. (1963) 'Sentencing - the Case for Reasoned Decisions', Criminal Law Review 10: 243-253.

THOMAS, J. B. (1997) Judicial Ethics in Australia. Sydney: LBC Information Services.

TYLER, T. R. (1984) 'The Role of Perceived Injustice in Defendants' Evaluations of Their Courtroom Experiences', Law and Society Review 18(1): 51-74.

TYLER, T. R. (1988) 'What Is Procedural Justice? Criteria Used by Citizens to Assess the Fairness of Legal Procedures', Law and Society Review 22(1): 103-135.

TYLER, T. R. (1990) Why People Obey the Law. New Haven, CT: Yale University Press.

TYLER, T. R. (2000) 'Social Justice: Outcome and Procedure', International Journal of Psychology 35(2): 117-125.

TYLER, T. R. (2003) 'Procedural Justice, Legitimacy and the Effective Rule of Law', Crime and Justice 30: 283-357.

TYLER, T. R. (2007-2008) 'Procedural Justice and the Courts', Court Review44(1/2): 26-31.

UNITED STATES SENATE COMMITTEE ON THE JUDICIARY (2009) 'Confirmation Hearing on the Nomination of Hon Sonia Sotomayor, to Be an Associate Justice of the Supreme Court of the United States'. Committee on the Judiciary.

US FEMINIST JUDGMENTS PROJECT (2015) About Us, online: (last accessed 20 March 2015).

VALVERDE, M. (2015) Chronotopes of Law: Jurisdiction, Scale and Governance. Abingdon: Routledge.

WEXLER, D. B. (2000) 'Therapeutic Jurisprudence: An Overview', Thomas M. Cooley Law Review 17(1): 125-134.

WEXLER, D.B. and WINICK, B.J. (1991) 'Therapeutic Jurisprudence as a New Approach to Mental Health Law Policy Analysis and Research', University of Miami Law Review 45: 979-1004. 
WEXLER, D.B. and WINICK, B.J. (2003) 'Putting Therapeutic Jurisprudence to Work', $A B A$ Journal, May: 54-57.

WIENER, R.L., WINICK, B.J., GEORGES, L.S. AND CASTRO, A. (2010) 'A Testable Theory of Problem-Solving Courts: Avoiding Past Empirical and Legal Failures', International Journal of Law and Psychiatry 33: 417-427.

WINICK, B.J. (2002-2003) 'Therapeutic Jurisprudence and Problem Solving Courts', Fordham Urban Law Journal30: 1055-1090.

WINICK, B.J. (2008-2009) 'Foreword: Therapeutic Jurisprudence Perspectives on Dealing with Victims of Crime', Nova Law Review 33: 535-543.

WINICK, B.J. and WEXLER, D.B. (2003) 'Introduction' in Judging in a Therapeutic Key: Therapeutic Jurisprudence and the Courts. Durham, NC: Carolina Academic Press.

WOMEN'S COURT OF CANADA Rewriting Equality, online: <http://womenscourt.ca/home/> (last accessed 2 March 2015).

WRIGHT, K. (2010) The Rise of the Therapeutic Society: Psychological Knowledge and the Contradictions of Cultural Change. Washington DC: New Academia.

\section{Case}

Were v Police [2003] SASC 116 